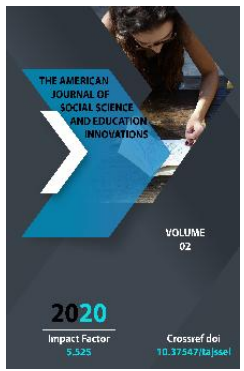

\title{
The Works Of Modern Jordanian Writer Ilias Farquh
}

\author{
Mukhiddinova Dilafruz Zokhriddinovna \\ Doctor Of Philological Sciences, Associate Professor Of The Department Of Literature Of \\ Foreign Eastern Countries, Tashkent State University Of Oriental Studies Tashkent, \\ Uzbekistan
}

Journal Website:

http://usajournalshub.c

om/index,php/tajssei

Copyright: Original

content from this work

may be used under the

terms of the creative

commons attributes

4.0 licence.

\section{ABSTRACT}

The study of short stories in Jordan in the early $60-80$ s of the 20th century shows that the problem of Palestine is one of the leading topics, received a deeper and more comprehensive coverage in their works. A characteristic side of the short story writers of Jordan 70-80s is that they take a biased antiIsraeli position. During this period, the writers create the short story which possesses a new form and content. It should be noted that the anti-Israeli position is characteristic of the short stories of Ilias Farquh, where the writer's short story "Abo, illuminating the silence", discusses the theme of the Palestinians who have become refugees in their homeland.

\section{KEYWORDS}

"an-Nahda", journalism, "Kissa kasira" (short story), realism, "Palestinian theme”, "anti - Israeli" position, retrospective plot, symbolic meaning, " abo " - outerwear.

\section{INTRODUCTION}

By the 1950s, the exodus of Palestinians had become a major theme in the literature of many Arab states, including Jordan. It is safe to say that this period was a great revolutionary period in intellectual and cultural life. Political processes in the Middle East have created a new social and cultural environment in the Arab world, including Jordan. "After the tragedy of 1948, the children of the two banks of the Jordan River merged. This society has endured the oppression of the Israeli occupation, the disintegration of the Palestinian people, and difficulties in the health, social, economic, and political spheres. All of this was covered in the prose of the time ${ }^{1}$. Khalil as-Sawahiri, Ahmad Udo, Fahri Kaavar, Mahmud Shukeyr, Yusuf

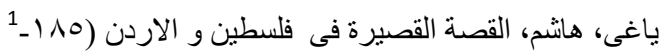

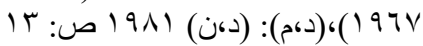


Zamra, Salim an-Nahas, Mufid Nahla, Ibrahim al-Khatib, Ibrahim al-Absi, Yusuf al-Hazw, Khalil Qindil, Ilias Farquh, Hashim Gharayiba , Mustafa Salih and other writers were members.

A study of the work of Jordanian storytellers in the early 1960 s and 1980 s shows that the Palestinian problem, one of the leading themes in their work, is described more deeply and comprehensively. A characteristic feature of the works of the Jordanian writers of the $70 \mathrm{~s}$ and 80s, the Children of Disaster (اللززي مة اب ناء), is that they are anti-Israel. "The Palestinian problem, which reflects the national identity of Jordanian literature, became especially serious in the 1970 s and $1980 \mathrm{~s}^{21}$. The Arab literary scholar Hussein Juma wrote in his article "The Palestinian Problem in Modern Jordanian Literature" that "the Palestinian question and the problem of displaced refugees were the main themes of modern Jordanian literature ${ }^{3 \prime}$.

One of the Jordanian writers is Ilias Farquh (Ilyas George Basil Farkouh) was born in 1948 in Ammon. He studied at the University of Beirut, majoring in Philosophy and Psychology. From 1977 to 1979 he worked in the editorial office of the newspaper "Madaniyat" and magazines "Madaniyat Asri". From 1980 to 1991 he worked in the publishing house, and in 1992 he founded the publishing house "Dar azmina" (House of Times) and was the director of this publishing house. He is one of the founders of the Jordanian Publishers Association and a member of this association, as well as the Union of Arab Writers, the

\footnotetext{
${ }^{2}$ Kovyrshina N.B. Prose of Jordan. do.gendocs / docs / index-89214... P.61.

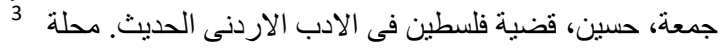

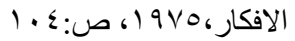

Jordanian Writers Association. His collection of short stories "21 Shots for the Prophet" won the "Best Collection of the Year" in 1982, as well as the novel "Foam" in 1992, and in 1997 won state awards for his contribution to storytelling. Elijah Farkouh's "Pages" (1978), "The Birds of Ammon Fly Slowly" (1981), "21 Shots for the Prophet" (1982), "Who Drives the Sea?" (1986), "Secrets of the Hourglass" (1991), "Angel in the Open Sky" (1995), "Winter Under the Roof" (2002), and many other collections of stories. Ilyas Farkouh was also involved in translation. He was also educated in England. Independently dealt with filmmaking and fine arts. Probably for this reason, these are reflected in his artistic worldview, his desire for clarity in the depiction of events, and his ability to reflect them on facts.

Ilias Farquh's story, “Eagles illuminating silence", was written in 1978 and published in al-Qaeda in Beirut. The author dedicates his work to Jihad Humuv who passed away and mentions this at the beginning of the story.

The protagonists of the story are women and townspeople. The woman's name is not mentioned in the play. The story is based on a retrospective plot and begins at the culmination:

He was wrapped in some kind of shroud with wide and long stripes that people were not wrapped in. The shortness of the shroud did not completely cover the body, and his legs protruded as if it were extra."

As you can see from the picture, at the beginning of the story there is a picture of an immigrant dying on the street.

The man was frustrated on the east side of town. None of the townspeople knew him. 
This is strange, because the people of this small town knew each other very well.

"We know the townspeople and the inhumane," he said. We know them one by one. We know who hates them, who is unemployed. We know both the homeless and those who are constantly imprisoned. We know the idiots in the rent, and even the babies to be born in the mother's womb. We know everything.

Here the writer draws the reader's attention to a number of "painful" problems of society. The increase in Jordan's population due to refugees causing unemployment, homelessness problems in the society. The number of refugees growing. Thousands of people are forced to look for work in other areas to support their families. Some people die as a result of political conflicts, various disasters. The author notes this throughout the work.

The protagonist of the story is a woman, and the course of events continues in harmony with the woman's inner experiences and thoughts. Leaning against the door of her house, the woman stares at the wall on the east side of town.

The woman, who saw cars passing by the barrier, did not give in to nightmares. The woman is the wife of a man who gave his life for Palestinian freedom. In this way, the author draws the reader's attention to the fact that political problems have not been solved for years, and the flow of refugees has not stopped. The protagonist of the story is also a representative of Arab women who are tired of political clashes, but still endure all the hardships. The woman is patient and resilient. She is a family person, trying to keep it a secret, even though she is tormented by the loss of her heart and the pain of waiting. The writer skillfully describes such mental states of the protagonist.

The dreamy woman remembers her husband's last words in anger.

"Patriotism is needed in great deeds from today !!"

These words of Iqab are a moving feeling in the hearts of Palestinians - love for the motherland, devotion to good deeds, a call to fight for freedom.

The woman has not seen her husband since. Such a tragedy was the tragedy not only of the protagonist of the work, but of all the women of the eastern city.

It is known from history that in 1949, the eastern part of Jerusalem came under the control of Jordan and the western part under the control of Israel. But after the 1967 Six Day War, the Israeli government occupied the Eastern city. This will cause great protests of the Arab people. The problem of the eastern city is still unresolved.

Unemployment has dispersed the poor, middle-class population of the eastern city in search of work. They are even looking for work in areas belonging to Israel. Someone dies on those sides. However, there is no human value in those aspects. In some cases, even the dead are left on the streets. The writer expresses this tragedy of the nation through the following conversations of women gathered under the wall.

- "The corpse has been lying in the sun since morning, which is not good."

Another woman said in surprise: 
- "Why don't they try?" After all, burying in time is good for the corpse.

- Another woman said with conviction:

- They say they do not allow it.

- "Who doesn't?"

- The first woman said:

- The guard at the post.

The woman did not succumb to all sorts of frightening fantasies. She sometimes thinks of her husband Iqab and sometimes of her son Hamadon. His son has not been seen since morning either. Suddenly the woman's imagination is shattered by the words of those gathered.

- He died in the south, they want to bury him here. He is a stranger.

- "He's no stranger." He was born here, but that place is also his homeland.

Although a number of Palestinian territories have been occupied by Israel, Palestinians also consider these lands as their homeland and will never give up hope of returning to their homeland. Ilyas Farkouh would like to emphasize this in the above conversation.

The fate of the dead will not be decided until late at night. In the middle of the night, while the guards are asleep, his (deceased's) friends come and steal without telling him. When darkness falls, a call is made for a funeral in the town.

Funeral details will be described throughout the work. These details remind the reader of a documentary.
The coffin appeared in the distance and was approached by the town's rifles (armed men). The coffin shook quietly and approached in an open position. The rifles rose and rose, as if ready to open fire. The soldiers were watching from a distance, and the women were gathering their children around them... The funeral procession lit up under the torches and approached the city gates.

The funeral was held under military supervision. The number of people coming to the funeral was increasing, which sounded like a new clash with the soldiers. The woman comes to her senses as her son Hamadon holds her hands. Her husband did not return home that night either. The morning had also begun. Hamadon said, "Mom, look at the bats," and clung to his mother's lap.

- "They're not bats, Hamadon, don't be afraid."

- Then he took a deep breath and added:

- Bats only go out at night.

- Hamadon asked again:

- "What's that?"

On the opposite east side, a black wing fluttered in the wind.

- "Hamadon, these are an army of eagles." An army of eagles.

At this point, Ilias Farquh strives for symbolism. By eagles he means Palestinians striving for freedom. Eagles strive for freedom, for distant heights. The flock of eagles is proud, they will never be defeated. 
The story is "Silence like a new grave"(سكون رتيب كالمقبرة الجديبة) "An ominous idea"(قلبها هاجس شؤم) ), "Torches flashing lightly like devils on houses"(المتشاعل كتباطين خفيفة فوق اللبيوت), "Heavy day"(النهار النقبقل), "The passion of

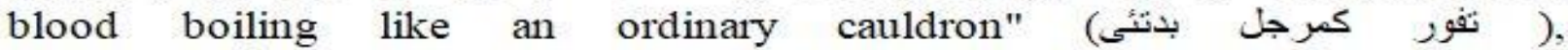

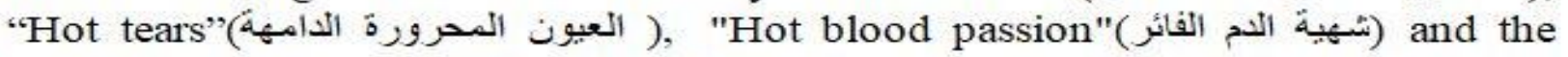
skillful use of various other analogies and expressions further enriched the content of the work.

In conclusion, a study of the work of Jordanian storytellers in the early 1960 s and 1980 s shows that the Palestinian problem, one of the leading themes in their work, is described more deeply and comprehensively. A characteristic feature of the works of Jordanian writers of the 70 and 80 s is that they are anti-Israel. Writers who worked during this period brought a new form and a new content to the story.

Ilias Farquh's story "Eagles illuminating the silence" also addresses the above issues. One of the unique features of the story is that it is built on a retrospective plot and begins at its culmination. In this way, the author manages to engage the reader and quickly draw his attention to the content of the story.

In the story, the author draws the reader's attention to a number of "painful" problems of society. The main theme of the work is the increase in the population of Jordan due to refugees, unemployment, homelessness in society, thousands of people forced to look for work in other areas to support their families, political conflicts, the death of innocent people as a result of various disasters. The story skillfully portrays the image of a woman who is tired of political conflicts, yet still endures all the hardships.

\section{REFERENCES}

1. Ashixmina N.P. O palestinskoy prose Soprotivleniya 60-x gg. (XX v.) // Arabic literature. Scientific works. № 697.-T .: 1982.

2. Muhiddinova DZ Formation and development of the Arab story of the XX century. Filol.f. d. (DSc) diss. abstracts. $-\mathrm{T}$.: 2017.

3. Juma H. Palestinian and Jordanian Novels in the 20th Century. Author's abstract. Cand. diss. - Moscow: 1973.26 p.

4. Kovyrshina NB Modern Jordanian short story (late 60s - early 80s). Author's abstract. Cand. diss. Moscow, 1985.

5. Kovyrshina N.B. Prose of Jordan. do.gendocs / docs / index-89214

6. The latest history of the Arab countries of Asia (1917-1985) .- M .: "Science", 1988. 


\section{Sources in Arabic}

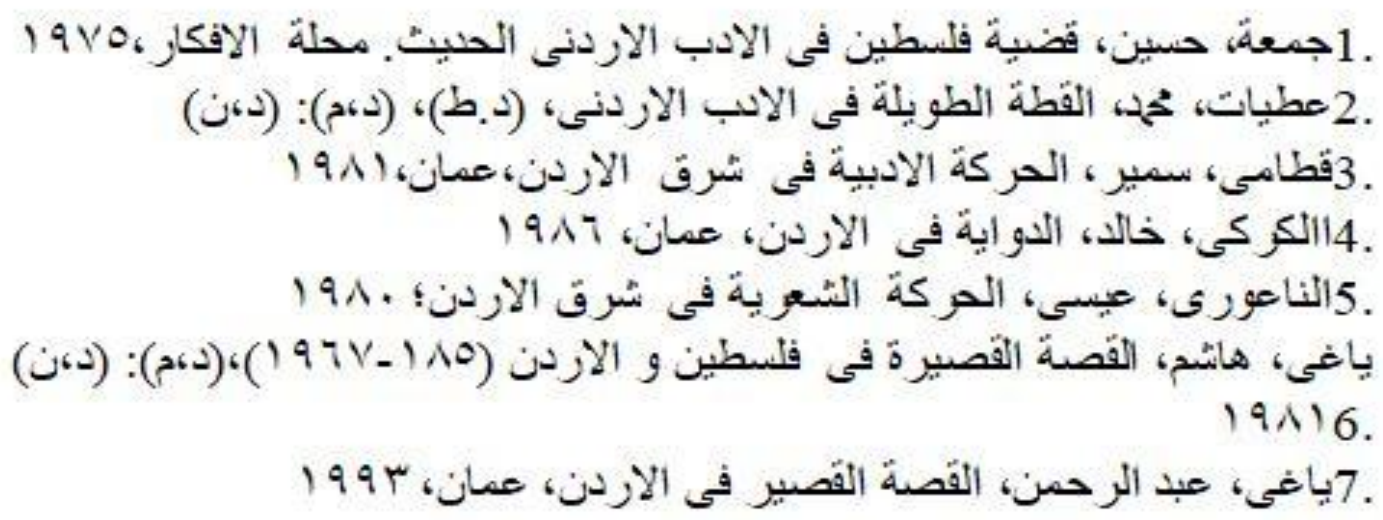

\section{Websites}

1. do.gendocs/ docs/index-89214... http://cheloveknauka.com/sovremennaya-iordanskayanovella-konets-60-h-nachalo-8o-h-godov

2. http://lib.ua-ru.net/diss/cont/210688.html

3. www.livelib.ru/tag/иорданская-литература 